\title{
Impact of temporomandibular disorders on quality of life
}

\author{
O impacto das disfunções temporomandibulares na qualidade de vida
}

\section{El impacto de las disfunciones temporomandibulares en la calidad de vida}

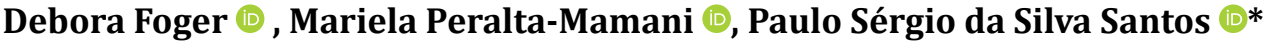

Universidade de São Paulo (USP), Bauru, SP, Brazil

Abstract

Introduction: Temporomandibular dysfunction (TMD) may have a major impact on quality of life. Objective: Thus, this integrative review assessed the impact of TMD on quality of life. Method: An electronic and manual search was conducted to identify studies that evaluated the impact of TMD on an individual's quality of life. After the inclusion and exclusion criteria were met, seven articles were included and evaluated according to the quality of evidence using the Newcastle-Ottawa assessment. Results: The selected studies used different instruments to diagnose temporomandibular joint disorders and measure the quality of life. Only three studies used the RDC/TMD. As for quality of life, the most used instrument was the SF-36, followed by Br-MPQ and WHOQOL-Bref. Conclusion: The findings show that there is a negative impact of temporomandibular dysfunction on quality of life, especially regarding its severity. However, further studies are needed to confirm these results.

Keywords: Temporomandibular Joint Disorders. Facial Pain. Quality of Life.

* DF: PhD, e-mail: deborafoger@usp.br MPM: Doctoral student, e-mail: marielaperalta@usp.br PSSS: PhD, e-mail: paulosss@fob.usp.br 
Resumo

Introdução: A disfunção temporomandibular (DTM) pode ter um grande impacto na qualidade de vida das pessoas. Objetivo: Esta revisão integrativa avaliou o impacto da DTM na qualidade de vida da população. Método: Uma busca eletrônica e manual foi realizada para identificar estudos que avaliaram o impacto da DTM na qualidade de vida. Após os critérios de inclusão e exclusão serem estabelecidos, seis artigos foram incluídos e avaliados de acordo com a qualidade de evidências utilizando o Newcastle-Ottawa. Resultados: Osestudosselecionadosutilizaraminstrumentos distintosparadiagnóstico daDTMeda mensuração daqualidade de vida. Os instrumentos de diagnóstico de DTM foram o Research Diagnostic Criteria for Temporomandibular Disorders (RDC/TMD), índice Anamnético de Fonseca, índice de Helkimo e índice Anamnético de Fonseca juntamente com RDC/TMD. Quanto à qualidade de vida, o instrumento mais utilizado foi o SF-36, seguido de Br-MPQ e WHOQOL-Bref. Conclusão: Os achados mostram que existe um impacto negativo da DTM na qualidade de vida, principalmente quanto a sua gravidade. Entretanto, futuras pesquisas são necessárias para confirmar esses resultados

Palavras-chave: Transtornos da Articulação Temporomandibular. Dor Facial. Qualidade de Vida.

\section{Resumen}

Introducción: La disfunción temporomandibular (DTM) puede tener un gran impacto en la calidad de vida de las personas. Objetivo: Esta revisión integrativa evaluó el impacto de la DTM en la calidad de vida de la población. Método: Se realizó una búsqueda electrónica y manual para encontrar estudios que evalúen el impacto de la DTM en la calidad de vida. Después de establecer los criterios de inclusión y exclusión, seis artículos fueron incluidos y evaluados según la calidad de evidencias utilizando la escala Newcastle - Ottawa. Resultados: Los estudios seleccionados utilizaron diversos instrumentos para el diagnóstico de la DTM y para medir la calidad de vida. Los instrumentos de diagnóstico de la DTM fueron Research Diagnostic Criteria for Temporomandibular Disorders (RDC/TMD), índice Anamnésico simplificado de Fonseca, índice de Helkimo e índice Anamnésico simplificado de Fonseca con RDC/TMD. Respecto a la calidad de vida, el instrumento más utilizado fue el SF-36, seguido de Br-MPQ y WHOQOL-Bref. Conclusión: Los resultados mostraron que existe un impacto negativo de la disfunción temporomandibular en la calidad de vida, principalmente respecto a su gravedad. No obstante, futuras investigaciones son necesarias para confirmar esos resultados.

Palabras clave: Trastornos de la Articulación Temporomandibular. Dolor Facial. Calidad de Vida.

\section{Introduction}

Temporomandibular dysfunction (TMD) involves musculoskeletal pain, disorders of mandibular movement patterns and/or impairment of functional movement [1-5]. It is also recognized as the most common non-odontogenic chronic condition of orofacial pain, in which pain is its main characteristic and the main reason for seeking treatment [6-15]. In addition to pain that is mostly aggravated by chewing and mandibular functions, individuals with TMD have asymmetric mandibular movements, joint noises and headache. In cases of constant and recurrent pain in the masticatory muscles, temporal region and/or the joint region itself, TMD may become a chronic condition; in these cases, although not risky, quality of life may be negatively affected [6,16-18]. Therefore, the use of instruments to assess the impact of TMD on quality of life is important to determine treatment needs and subsequent therapeutic successes [4].

In examining the literature, we only found one systematic review by Dahlström and Carlsson [19] showing that TMD has a negative impact on oral healthrelated quality of life, and we then realized that TMD could also affect overall quality of life. Therefore, this integrative review was performed to assess this issue. 


\section{Materials and methods}

Focus question

This study was conducted to answer the question: "What is the impact of temporomandibular dysfunction on overall quality of life?"

\section{Search strategy}

The following databases were searched: PubMed, LILACS, SciELO, Cochrane, as well as a manual search of the reference lists of selected studies to include articles that met the eligibility criteria. Only articles published between 2000 and 2017 were included. A search strategy was adapted for use in each database, and the keywords used for the search were: "Temporomandibular joint disorders" (MESH), "Facial pain" (MESH) AND "Quality of life" (MESH); "Temporomandibular Joint Disorders" (DECS), "Facial Pain" (DECS) AND "Quality of Life" (DECS). We also searched for articles from the references of the selected articles and in gray literature. Studies were identified first by reading titles and abstracts, then followed by full-text reading of potentially eligible studies.

Inclusion and exclusion criteria

Articles were selected according to the following inclusion criteria: articles published after 2000, in Portuguese or English, and addressing crosssectional, case-control and/or cohort studies that related TMD and overall quality of life.

We excluded the articles that were a literature review, case report and/or case series that evaluated TMD in individuals with degenerative diseases, such as juvenile idiopathic arthritis, and individuals with dentofacial deformities. Articles that evaluated only chronic TMD, populations of children and adolescents under 18 , and that used quality of life instruments specific for determining impact of oral health were also excluded [20, 21].

Main outcome

The main outcome was to determine the impact of TMD on quality of life.
Quality assessment

Quality assessment for cross-sectional studies was performed using the Newcastle- Ottawa Quality Assessment Scale, as recommended by the Cochrane Collaboration Guidelines for the evaluation of nonrandomized studies [22,23].

Studies were evaluated in three categories (selection, comparability, and results) based on the incorporation of designelementsassociated with decreased bias. Thestudy received stars $\left(^{*}\right)$ if it complied with the scale [23].

\section{Results}

\section{Study selection}

The search strategy yielded a total of 205 articles; 19 articles were selected for full-text reading, and 13 were excluded for not meeting the eligibility criteria; five evaluated TMD and quality of life. In patients with degenerative diseases, four used specific instruments to determine the impact of oral health on quality of life, two were case series, one was a case report and one evaluated a population under 18 years. At the end, a total of 6 articles were included, as illustrated in Figure 1. A total of 463 patients were included in the studies.

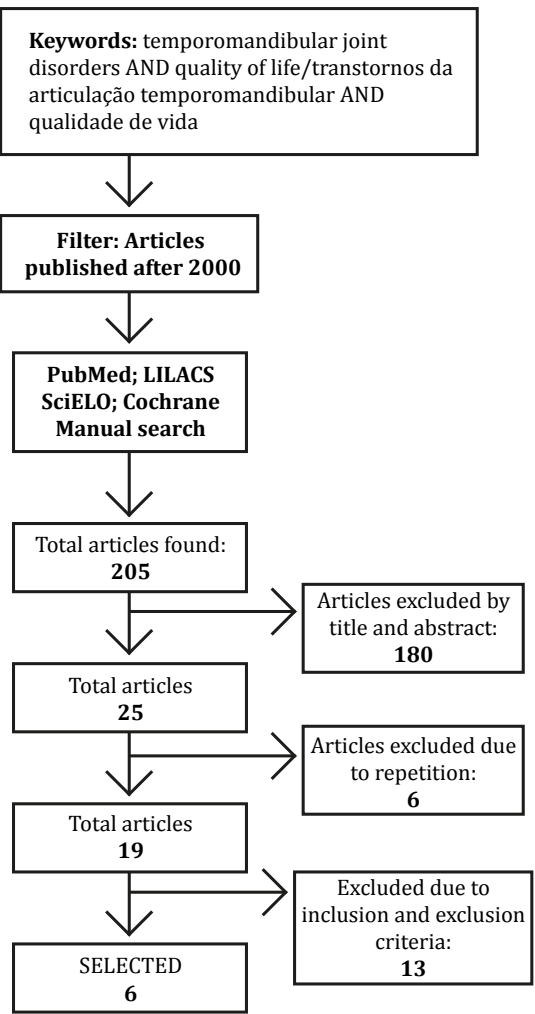

Figure 1 - Study selection. 


\section{Description of the studies}

In the articles reviewed (Table 1), TMD was evaluated using the following instruments: RDC/TMD [11], Fonseca Anamnestic Index [24, 25] and Helkimo Index [26]. One study did not specify the instrument used to assess TMD [27], and another used the Fonseca Anamnestic Index along with RDC/TMD [28]. The studies measured quality of life with the following instruments: SF-36 [11, 24, 26] Br-MPQ [27] and WHOQOL-Bref [28].

One of the articles divided the sample into three different subgroups: patients with TMD complaints for less than 1 year (subgroup 1), patients with TMD complaints for 1 to 3 years (subgroup 2) and patients with TMD complaints for more than 3 years (subgroup 3) [11]. Subsequently, two studies $[11,28]$ classified the patients according to RDC/TMD criteria: group A - myofascial pain; group B - disk displacement; and group $\mathrm{C}$ - arthralgia, osteoarthritis and osteoarthrosis.

All articles concluded that there was a negative impact on the quality of life of patients with TMD, especially regarding the social, psychological and mental aspects of the individuals; one article also concluded that there was a relation between TMD severity and worsening of quality of life [11]. No article described sample calculation.

\section{Results for quality of life}

The SF-36 instrument $[29,30]$, used by most of the selected studies to measure quality of life, is currently one of the most used instruments in literature; it is composed of 36 items in 8 domains, of which 4 correspond to physical aspects (functional capacity, physical ability, general health and pain) and 4 to mental aspects (emotional aspect, social aspect, mental health and vitality) [11]. Of the four studies that used SF-36 to measure quality of life [11, 24, 25, 26], three showed that the vitality domain had the worst score among TMD patients [11, 23, 24], and one compared patients who had TMD for less than one year (group I), for 1 to 3 years (group II) and for more than 3 years (group III) [11]. There was a statistically significant difference between patients in group I versus group III, with physical functioning and pain scores being worse in group III patients; no such difference was found between group II and III patients.

Another instrument to assess quality of life was Br-MPQ [27], which analyzes the findings regarding the impact of pain on the individual's life. The authors reported that the impact of pain on daily living activities, the subtypes sleep (68.18\%) and appetite/eating (63.64\%) showed the highest percentages of responses with some degree of impairment ( $p>0.05$ ). In addition, $77.27 \%$ of individuals with TMD had difficulty tolerating pain ( $p>0.05 \%$ ) [26].

One study used the quality of life instrument WHOQOL-Bref [28], which consists of 26 questions divided into four domains: physical, psychological, social and environmental $[28,31]$. The results showed an association between the social domain of quality of life in the disk displacement group, with and without reduction with limited opening in the RDC-TMD. 


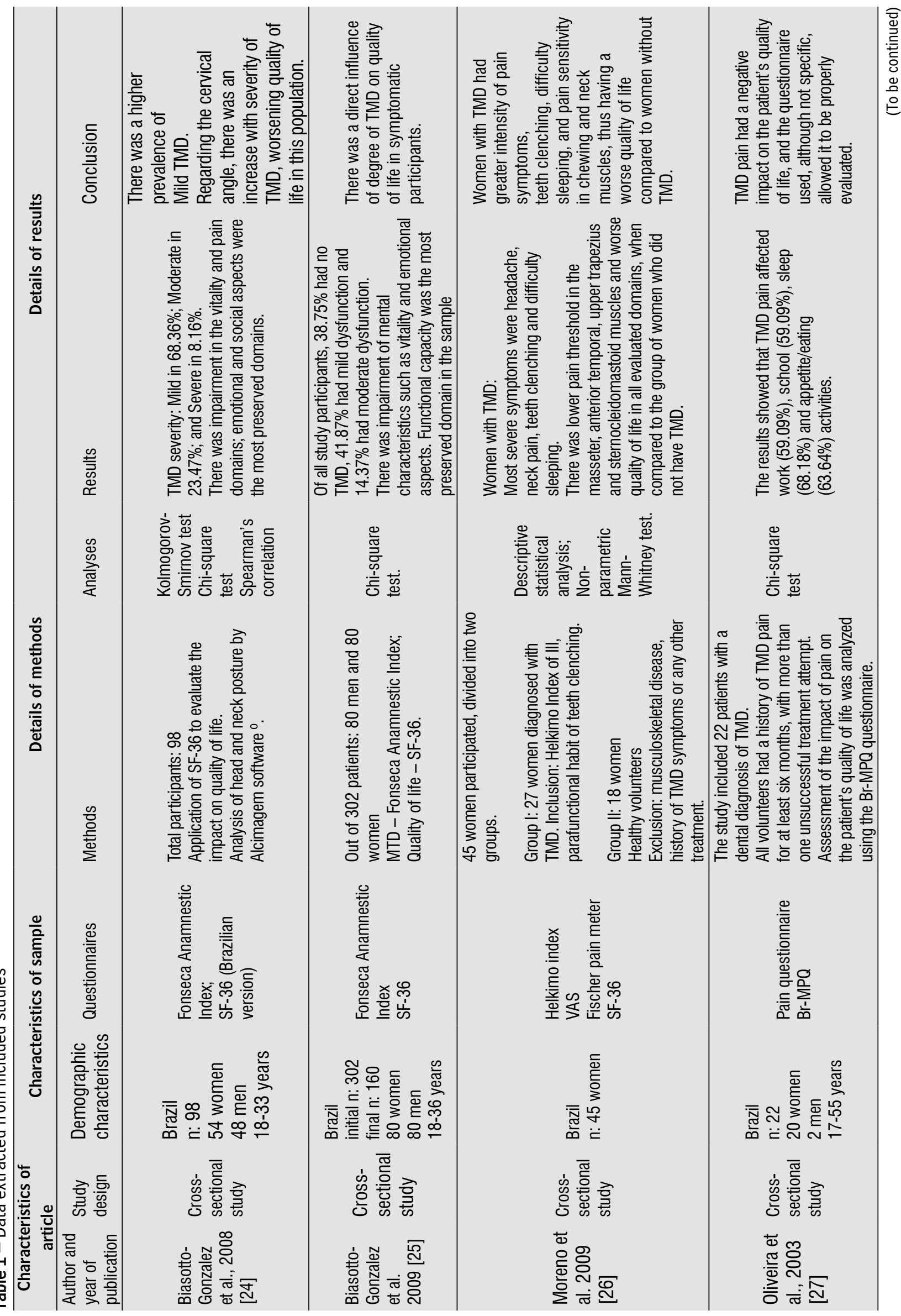




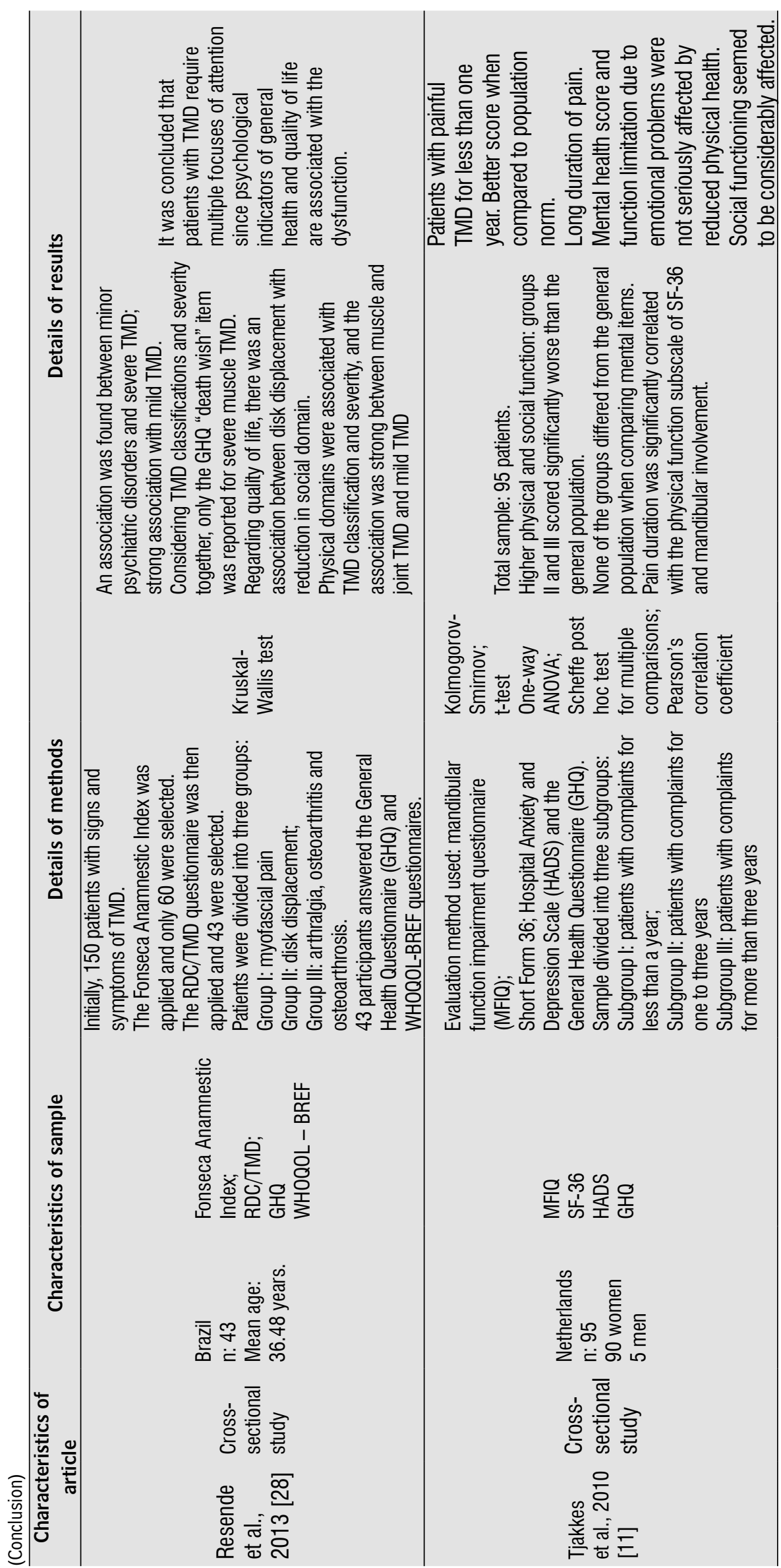


Quality assessment

Quality assessment revealed that, out of a total of 9 stars ${ }^{*}$ ) that could be awarded to articles according to each item, three studies received 4 stars $[11,26,28]$ and were rated moderate, and three received 3 stars [24, 25, 27] and were classified as low quality (Table 2).

Table 2 - Newcastle-Ottawa quality assessment

\begin{tabular}{|c|c|c|c|c|}
\hline \multicolumn{5}{|c|}{ Identification of study Newcastle-Ottawa quality assessment } \\
\hline References & $\begin{array}{l}\text { Type of } \\
\text { study }\end{array}$ & Selection & Comparability & Results \\
\hline $\begin{array}{c}\text { Biasotto- } \\
\text { Gonzalez et al., } \\
{[24]}\end{array}$ & $\begin{array}{l}\text { Cross- } \\
\text { sectional }\end{array}$ & * & * & * \\
\hline $\begin{array}{c}\text { Biasotto- } \\
\text { Gonzalez et al., } \\
{[25]}\end{array}$ & $\begin{array}{l}\text { Cross- } \\
\text { sectional }\end{array}$ & * & * & * \\
\hline $\begin{array}{l}\text { Moreno et al., } \\
\text { [26] }\end{array}$ & $\begin{array}{l}\text { Cross- } \\
\text { sectional }\end{array}$ & ** & * & * \\
\hline $\begin{array}{c}\text { Oliveira et al., } \\
\text { [27] }\end{array}$ & $\begin{array}{l}\text { Cross- } \\
\text { sectional }\end{array}$ & * & * & * \\
\hline $\begin{array}{l}\text { Resende et al., } \\
\text { [28] }\end{array}$ & $\begin{array}{l}\text { Cross- } \\
\text { sectional }\end{array}$ & ** & * & * \\
\hline $\begin{array}{c}\text { Tjakkes et al., } \\
{[11]}\end{array}$ & $\begin{array}{c}\text { Cross- } \\
\text { sectional }\end{array}$ & ** & * & * \\
\hline
\end{tabular}

\section{Discussion}

TMD has been the subject of both clinical and epidemiological studies, not only in investigations regarding treatment, but also to find out how much does this disease, which is becoming increasingly common among people, negatively affects quality of life [32-36]. The results of this review showed that TMD has a negative impact on people's quality of life.

Different results were reported regarding the diagnostic classification of TMDs found in the participants, and this discrepancy was due to the use of different assessment and diagnostic instruments and to the way data was collected. Studies which evaluated patients from specialized clinics or who sought treatment $[11,28]$ had more patients with moderate or severe TMD, while patients from a population that was not seeking treatment $[24,26]$ showed a more pronounced percentage of mild TMD. Defining exactly how data will be collected and which population will be studied is of utmost importance for the analysis of the final results, since results found in a population seeking specific treatment for dysfunction are not considered valid for the general population. This issue should be analyzed in future studies.

It is known that systemic and/or degenerative diseases, and musculoskeletal diseases as well, might be a confounding factor in the diagnosis of TMD, since they have a multifactorial etiopathogenesis $[8,37,38]$. Along the same line, it is clear from scientific literature that only three articles included in this review considered systemic, degenerative and/or musculoskeletal diseases as exclusion factors $[24,26,28]$. The other studies did not report these diseases as such.

An important issue that has been suggested is the standardization of the instruments for TMD assessment and diagnosis, since it is very difficult to compare studies that diagnosed TMD more fully, such as those with the use of RDC/TMD $[28,39]$, with studies that used simpler diagnostic instruments. Only three articles used the RDC/TMD, which were also the studies that obtained the best classification in the quality assessment according to the Newcastle-Ottawa instrument [22]. According to these studies, the presence of muscle disorders (group I), osteoarthritis (group III) and orofacial pain had a major impact on the quality of life of individuals with TMD. In addition, the long duration of pain seriously affected social functioning [11, 28].

Despite the differences in the studies regarding the instruments used for TMD diagnosis and quality of life measurement, homogeneity could be observed, since we used a rigorous methodological design in the quality assessment of the studies performed, by the application of the NewcastleOttawa Scale $[22,40]$. However, the risk of bias due to the small number of articles included cannot be excluded.

The results of our integrative review showed that TMD has a negative impact on quality of life, especially regarding its severity, seriously affecting social functioning [41]. A limitation of this review was that, of the six studies eligible for inclusion in this review, no study reported sample calculation. Quality assessment revealed that three articles were at risk of bias. The adequate methodological design of the studies, as well as sample calculations to define the sample size, with the objective of internal and external validations, will be necessary in future studies to confirm the results obtained in this review. 


\section{Conclusion}

TMD has a negative impact on quality of life, especially regarding its severity. Important questions were reported on the standardization of the instruments used for TMD diagnosis and assessment, and also on the confounding factors caused by the non-exclusion of individuals with systemic/degenerative and musculoskeletal diseases in the samples studied. Due to the small number of studies available, further research is needed.

\section{References}

1. Bastos RS, Carvalho ES, Xavier A, Caldana ML, Bastos JRM, Lauris JRP. Dental caries related to quality of life in two Brazilian adolescent groups: a cross-sectional randomised study. Int Dent J. 2012;62(3):137-43.

2. Sischo L, Broder HL. Oral health-related quality of life: what, why, how, and future implications. J Dent Res. 2011;90(11):1264-70.

3. Allen PF. Assessment of oral health related quality of life. Health Qual Life Outcomes. 2003;1(40):1-8.

4. Barros VM, Siraidairan PI, Cortes MIS, Paula LV. The impact of orofacial pain on the quality of life of patients with temporomandibular disorder. J Orofac Pain. 2009;23(1):28-37.

5. Greene CS. The etiology of temporomandibular disorders: implications for treatment. J Orofac Pain. 2001;15(2):93-105.

6. Conti PCR, Pinto-Fiamengui LMS, Cunha CO, Conti ACCF. Orofacial pain and temporomandibular disorders: the impact on oral health and quality of life. Braz Oral Res. 2012;26(1):120-3.

7. Oliveira W. Disfunções temporomandibulares. São Paulo: Artes Médicas; 2002.

8. Carrara SV, Conti PCR, Barbosa JS. Termo do 1 o Consenso em disfunção temporomandibular e dor orofacial. Dental Press J Orthod. 2010;15(3):114-20.
9. Pizolato RA, Fernades FSF, Gavião MBD. Anxiety/ depression and orofacial myofacial disorders as factors associated with TMD in children. Braz Oral Res. 2013;27(2):156-62.

10. Raphael KG, Janal MN, Sirois DA, Svensson P. Effect of contingent electrical stimulation on masticatory muscle activity and pain in patients with a myofascial temporomandibular disorder and sleep bruxism. J Orofac Pain. 2013;27(1):21-31.

11. Tjakkes GHE, Reinders JJ, Tenvergert EM, Stegenga B. TMD pain: the effect on health-related quality of life and the influence of pain duration. Health Qual Life Outcomes. 2010;8(46):1-8.

12. Aldridge RD, Fenlon MR. Prevalence of temporomandibular dysfunction in a group of scuba divers. Br J Sports Med. 2004;38(1):69-73.

13. Feteih RM. Signs and symptoms of temporomandibular disorders and oral parafunctions in urban Saudi Arabian adolescents: a research report. Head Face Med. 2006;2(25):1-7.

14. Silveira AM, Feltrin PP, Zanetti RV, Mautoni MC. Prevalência de portadores de DTM em pacientes avaliados no setor de otorrinolaringologia. Rev Bras Otorrinolaringol. 2007;73(4):528-32.

15. Dawson PE. Diagnóstico diferencial da síndrome da articulação temporomandibular: avaliação, diagnóstico e tratamento dos problemas oclusais. St. Louis: Artes Médicas; 1980.

16. Silva MMA, Ferreira AT, Migliorucci RR, Nari Filho H, Berretin-Felix G. Influência do tratamento ortodôntico-cirúrgico nos sinais e sintomas de disfunção temporomandibular em indivíduos com deformidades dentofaciais. Rev Soc Bras Fonoaudiol. 2011;16(1):80-4.

17. Schlenk EA, Erlen JA, Dunbar-Jacob J, McDowell J, Engberg S, Sereika SM et al. Health related quality of life in chronic disorders: a comparison across studies using the MOS SF-36. Qual Life Res. 1998;7(1):57-65.

18. Reisine ST, Weber J. The effects of temporomandibular joint disorders on patients' quality of life. Comm Dent Health. 1989;6(3):257-70. 
19. Dahlström L, Carlsson GE. Temporomandibular disorders and oral health-related quality of life. A systematic review. Acta Odontol Scand. 2010;68(2):80-5.

20. Sgalastra F, Gatto R, Petrucci A, Monaco A. Effectiveness of systemic amoxicillin/metronidazole as adjunctive therapy to scaling and root planing in the treatment of chronic periodontitis: a systematic review and metaanalysis. J Periodontol. 2012;83(10):1257-69.

21. Hayden C, Bowler JO, Chambers S, Freeman R, Humphris G, Richards D, et al. Obesity and dental caries in children: a systematic review and meta-analysis. Community Dent Oral Epidemiol. 2013;41(4):289-308.

22. Wells G, Shea B, O'Connell D, Peterson J, Welch V, Losos M, et al. The Newcastle-Ottawa Scale (NOS) for assessing the quality of nonrandomised studies in meta-analyses. The Ottawa Hospital [cited 2001 Feb 1]. Available from: http://bit.ly/35sOvHM.

23. Marsicano JA, Moura-Grec PG, Bonato RCS, Sales-Peres MC, Sales- Peres A, Sales-Peres SHC. Gastroesophogeal reflux, dental erosion, and halitosis in epidemiological surveys: a systematic review. Eur J Gastroenterol Hepatol. 2013;25(2):135-41.

24. Biasotto-Gonzalez DA, Andrade DV, Gonzalez TO, Martins MD, Fernandes KPS, Corrêa JCF, et al. Correlação entre disfunção temproromandibular, postura e qualidade de vida. Rev Bras Crescimento Desenvolv Hum. 2008;18(1):79-86.

25. Biasotto-Gonzalez DA, Mendes PCC, Jesus LA, Martins MD. Qualidade de vida em portadores de disfunção temporomandibular: um estudo transversal. Rev Inst Cienc Saude. 2009;27(2):128-32.

26. Moreno BGD, Maluf AS, Marques AP, Crivello-Júnior O. Avaliação clínica e da qualidade de vida de indivíduos com disfunção temporomandibular. Rer Bras Fisioter. 2009;13(3):210-4.

27. Oliveira AS, Bermudez CC, Dias EM, Castro CES, Bergin F. Impacto da dor na vida de portadores de disfunção temporomandibular. Jappl Oral Sci. 2003;11(2):138-43.
28. Resende CMBM, Alves ACM, Coelho LT, Alchieri JC, Roncalli AG, Barbosa GAS. Quality of life and general health in patients with temporomandibular disorders. Braz Oral Res. 2013;27(2):116-21.

29. Aaronson NK, Muller M, Cohen PDA, Essink-Bot ML, Fekkes M, Sanderman R, et al. Translation, validation and norming of the Dutch language version of the SF36 health survey in community and chronic disease populations. J Clin Epidemiol. 1998;51(11):1055-68.

30. Ciconelli RM, Feraz MB, Santos W, Meinão I, Quaresma MR. Tradução para a língua portuguesa e validação do questionário genérico de avaliação de qualidade de vida SF-36. Rev Bras Reumatol. 1999;39(3):143-50.

31. WHOQOL Group. The World Health Organization quality of life assessment (WHOQOL): position paper from the World Health Organization. Soc Sci Med. 1995;41(10):1403-9.

32. LeResche L, Dworkin DF, Wilson L, Ehrlich KJ. Effect of temporomandibular disorder pain duration on facial expressions and verbal report. Pain. 1992;51(3):289-95.

33. McNeill C, Danzig WM, Farrar WB, Gelb H, Lerman MD, Moffett BC, et al. Position paper of the American Academy of Craniomandibular Disorders. Craniomandibular (TMJ) disorders - the state of the art. J Prosthet Dent. 1980;44(4):434-7.

34. Murray H, Locker D, Mock D, Tenenbaum HC. Pain and the quality of life in patients referred to a craniofacial pain unit. J Orofac Pain. 1996;10(4):316-23.

35. Bernhardt O, Gesch D, Schwahn C, Mack F, Meyer G, John U, et al. Risk factors headache, including TMD signs and symptoms, and their impact on quality of life: results of the Study of Health in Pomernia (SHIP). Quintenssence Int. 2005;36(1):55-64.

36. Jedel E, Carlsson J, Stener-Victorin E. Health-related quality of life in child patients with temporomandibular disorder pain. Eur J Pain. 2007;11(5):557-63. 
37. Bezerra BPN, Ribeiro AIAM, Farias ABL, Farias ABL, Fontes LBC, Nascimento SR, et al. Prevalência da disfunção temporomandibular e de diferentes níveis de ansiedade em estudantes universitários. Rev Dor. 2012;13(3):235-42.

38. Yatani H, Studts J, Cordova M, Carlson CR, Okeson JP. Comparison of sleep quality and clinical and psychologic characteristics in patients with temporomandibular disorders. J Orofac Pain. 2002;16(3):221-8.

39. Dworkin SF, LeResche L. Research diagnostic criteria for temporomandibular disorders: review, criteria, examinations and specifications, critique. J Craniomandib Disord. 1992;6(4):301-55.

40. Moher D, Liberati A, Tetzlaff J, Altman DG. Preferred reports items for systematic reviews and metaanalyses: the PRISMA statement. Ann Intern Med. 2009;151(4):264-9.
41. Aggarwal VR, Lovell K, Peters S, Javidi H, Joughin A, Goldthorpe J. Psychosocial interventions for the management of chronic orofacial pain. Cochrane Database Syst Rev. 2011;9(11):CD008456.
Received in 01/04/2018

Recebido em 04/01/2018

Recibido en 04/01/2018

Approved in 11/07/2019 Aprovado em 07/11/2019 Aprobado en 07/11/2019 